\title{
Front Matter: Volume 8967
}

, "Front Matter: Volume 8967," Proc. SPIE 8967, Laser Applications in Microelectronic and Optoelectronic Manufacturing (LAMOM) XIX, 896701 (27 March 2014); doi: 10.1117/12.2063203

SPIE. Event: SPIE LASE, 2014, San Francisco, California, United States 


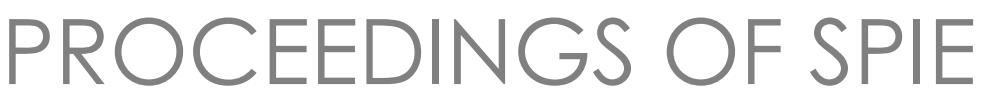

\title{
Laser Applications in Microelectronic and Optoelectronic Manufacturing (LAMOM) XIX
}

\author{
Yoshiki Nakata \\ Xianfan Xu \\ Stephan Roth \\ Beat Neuenschwander \\ Editors
}

3-6 February 2014

San Francisco, California, United States

Sponsored by

SPIE

Cosponsored by

Okamoto Optics (Japan)

Published by

SPIE 
The papers included in this volume were part of the technical conference cited on the cover and title page. Papers were selected and subject to review by the editors and conference program committee. Some conference presentations may not be available for publication. The papers published in these proceedings reflect the work and thoughts of the authors and are published herein as submitted. The publisher is not responsible for the validity of the information or for any outcomes resulting from reliance thereon.

Please use the following format to cite material from this book:

Author(s), "Title of Paper," in Laser Applications in Microelectronic and Optoelectronic Manufacturing (LAMOM) XIX, edited by Yoshiki Nakata, Xianfan Xu, Stephan Roth, Beat Neuenschwander, Proceedings of SPIE Vol. 8967 (SPIE, Bellingham, WA, 2014) Article CID Number.

ISSN: 0277-786X

ISBN: 9780819498809

Published by

SPIE

P.O. Box 10, Bellingham, Washington 98227-0010 USA

Telephone +1 3606763290 (Pacific Time) · Fax +1 3606471445

SPIE.org

Copyright (@ 2014, Society of Photo-Optical Instrumentation Engineers.

Copying of material in this book for internal or personal use, or for the internal or personal use of specific clients, beyond the fair use provisions granted by the U.S. Copyright Law is authorized by SPIE subject to payment of copying fees. The Transactional Reporting Service base fee for this volume is $\$ 18.00$ per article (or portion thereof), which should be paid directly to the Copyright Clearance Center (CCC), 222 Rosewood Drive, Danvers, MA 01923. Payment may also be made electronically through CCC Online at copyright.com. Other copying for republication, resale, advertising or promotion, or any form of systematic or multiple reproduction of any material in this book is prohibited except with permission in writing from the publisher. The CCC fee code is 0277-786X/14/\$18.00.

Printed in the United States of America.

Publication of record for individual papers is online in the SPIE Digital Library.

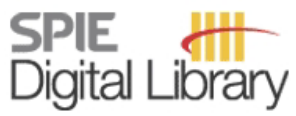

SPIEDigitallibrary.org

Paper Numbering: Proceedings of SPIE follow an e-First publication model, with papers published first online and then in print and on CD-ROM. Papers are published as they are submitted and meet publication criteria. A unique, consistent, permanent citation identifier (CID) number is assigned to each article at the time of the first publication. Utilization of CIDs allows articles to be fully citable as soon as they are published online, and connects the same identifier to all online, print, and electronic versions of the publication. SPIE uses a six-digit CID article numbering system in which:

- The first four digits correspond to the SPIE volume number.

- The last two digits indicate publication order within the volume using a Base 36 numbering

system employing both numerals and letters. These two-number sets start with 00, 01, 02, 03, 04, 05, 06, 07, 08, 09, 0A, 0B ... 0Z, followed by 10-1Z, 20-2Z, etc.

The CID Number appears on each page of the manuscript. The complete citation is used on the first page, and an abbreviated version on subsequent pages. Numbers in the index correspond to the last two digits of the six-digit CID Number. 


\section{Contents}

ix Conference Committee

LASER-INDUCED MODIFICATION AND PATTERNING OF SURFACES I: JOINT SESSION WITH CONFERENCES 8967 AND 8969

896704 Real-time adaptive optimization of laser induced nano ripples by laser pulse shaping [8967-3]

P. Srisungsitthisunti, King Mongkut's Univ. of Technology North Bangkok (Thailand);

M. Zamfirescu, L. P. Neagu, National Institute for Lasers, Plasma and Radiation Physics

(Romania); N. Faure, R. Stoian, Lab. Hubert Curien, CNRS, Univ. de Lyon, Univ. Jean Monnet (France)

LASER-INDUCED MODIFICATION AND PATTERNING OF SURFACES II: JOINT SESSION WITH CONFERENCES 8967 AND 8969

896705 Laser-induced patterns on metals and polymers for biomimetic surface engineering (Invited Paper) [8967-4]

A.-M. Kietzig, J. Lehr, L. Matus, F. Liang, McGill Univ. (Canada)

NANOMATERIAL PHOTONICS AND PLASMONICS I: JOINT SESSION WITH CONFERENCES 8967 AND 8969

896707 Optothermal response of plasmonic nanofocusing lens under picosecond laser irradiation (Invited Paper) [8967-6]

Z. Du, C. Chen, L. Traverso, X. XU, L. Pan, Purdue Univ. (United States); I.-H. Chao,

A. S. Lavine, Univ. of California, Los Angeles (United States)

ULTRAFAST LASER-INDUCED MODIFICATIONS OF TRANSPARENT MATERIALS: JOINT SESSION WITH CONFERENCES 8967 AND 8972

896708 Femtosecond laser 3D nanofabrication in glass: enabling direct write of integrated micro/nanofluidic chips (Invited Paper) [8967-7]

Y. Cheng, Y. Liao, Shanghai Institute of Optics and Fine Mechanics (China); K. Sugioka, RIKEN-SIOM Joint Research Unit (Japan)

896709 Flexible metal patterning in glass microfluidic structures using femtosecond laser directwrite ablation followed by electroless plating [8967-8]

J. XU, K. Midorikawa, K. Sugioka, RIKEN (Japan) 
8967 OA Nanosecond laser-induced back side wet etching of fused silica with a copper-based absorber liquid [8967-9]

P. Lorenz, Leibniz-Institut für Oberflächenmodifizierung e.V. (Germany); S. Zehnder, Bern Univ. of Applied Sciences (Switzerland); M. Ehrhardt, F. Frost, K. Zimmer, Leibniz-Institut für Oberflächenmodifizierung e.V. (Germany); P. Schwaller, Bern Univ. of Applied Sciences (Switzerland)

8967 OB Picosecond-laser bulk modification, luminescence, and Raman lasing in single-crystal diamond [8967-10]

B. Neuenschwander, B. Jaeggi, V. Romano, Bern Univ. of Applied Sciences (Switzerland); S. M. Pimenov, A. M. Prokhorov General Physics Institute (Russian Federation)

8967 0C Dynamics of interference of femtosecond laser-induced stress waves and crack formation inside a Lif single crystal [8967-11]

M. Sakakura, N. Fukuda, Y. Shimotsuma, K. Miura, Kyoto Univ. (Japan)

ADAPTIVE OPTICS AND BEAM SHAPING: JOINT SESSION WITH CONFERENCES 8967 AND 8972

8967 OF Femtosecond laser processing and spatial light modulator (Invited Paper) [8967-14]

K. Paivasaari, M. Silvennoinen, Univ. of Eastern Finland (Finland); J. Kaakkunen, VTT

Technical Research Ctr. of Finland (Finland); P. Vahimaa, Univ. of Eastern Finland (Finland)

8967 OG Focal length stabilization of a tunable lens integrated focus shifting unit [8967-15]

G. Eberle, B. Boesser, ETH Zürich (Switzerland); K. Wegener, ETH Zürich (Switzerland) and Inspire AG (Switzerland)

ULTRASHORT PULSE MICROMACHINING: JOINT SESSION WITH CONFERENCES 8967 AND 8972

$8967 \mathrm{OH}$ Influence of laser parameters on quality of microholes and process efficiency [8967-16] A. Feuer, C. Kunz, Univ. Stuttgart (Germany); M. Kraus, Robert Bosch GmbH (Germany); V. Onuseit, R. Weber, T. Graf, Univ. Stuttgart (Germany); D. Ingildeev, F. Hermanutz, Institut für Textilchemie und Chemiefasern Denkendorf (Germany)

\section{MATERIALS FOR ENERGY CONSERVATION}

8967 0J Laser cutting of carbon fiber reinforced thermo-plastics (CFRTP) by single-mode fiber laser irradiation [8967-18]

H. Niino, Y. Kawaguchi, T. Sato, A. Narazaki, Advanced Laser and Process Technology Research Association (Japan) and National Institute of Advanced Industrial Science and Technology (Japan); R. Kurosaki, Advanced Laser and Process Technology Research Association (Japan); M. Muramatsu, Y. Harada, Advanced Laser and Process Technology Research Association (Japan) and National Institute of Advanced Industrial Science and Technology (Japan); K. Anzai, M. Aoyama, Advanced Laser and Process Technology Research Association (Japan) and Miyachi Corp. (Japan); M. Matsushita, K. Furukawa, 
Advanced Laser and Process Technology Research Association (Japan) and Shin Nippon Koki Co. Ltd. (Japan); M. Nishino, Advanced Laser and Process Technology Research Association (Japan) and Mitsubishi Chemical Corp. (Japan); A. Fujisaki, T. Miyato, T. Kayahara, Advanced Laser and Process Technology Research Association (Japan) and Furukawa Electric Co., Ltd. (Japan)

8967 OK Laser trepanning of CFRP with a scanner head for IR and UV lasers [8967-19] K. Anzai, M. Aoyama, Advanced Laser and Process Technology Research Association (Japan) and Miyachi Corp. (Japan); A. Fujisaki, T. Miyato, T. Kayahara, Advanced Laser and Process Technology Research Association (Japan) and Furukawa Electric Co., Ltd. (Japan); Y. Harada, H. Niino, Advanced Laser and Process Technology Research Association (Japan) and National Institute of Advanced Industrial Science and Technology (Japan)

8967 OL Ablation dynamics and shock wave expansion during laser processing of CFRP with ultrashort laser pulses [8967-20]

M. Wiedenmann, C. Haist, C. Freitag, V. Onuseit, R. Weber, T. Graf, Univ. Stuttgart

(Germany)

8967 OM Analysis of laser ablation dynamics of CFRP in order to reduce heat affected zone [8967-21]

Y. Sato, M. Tsukamoto, Osaka Univ. (Japan); T. Nariyama, Kinki Univ. (Japan); K. Nakai, Osaka Univ. (Japan); F. Matsuoka, Kinki Univ. (Japan); K. Takahashi, S. Masuno, Osaka Univ. (Japan); T. Ohkubo, Tokyo Institute of Technology (Japan); H. Nakano, Kinki Univ. (Japan)

ENHANCED PROCESSING BY MULTI-PULSE

8967 ON Application of a laser heterodyne technique to characterize surface acoustic waves generated via a pulsed laser excitation [8967-22]

A. J. Manzo, H. Helvajian, The Aerospace Corp. (United States)

896700 Maximizing laser ablation efficiency of silicon through optimization of the temporal pulse shape [8967-23]

A. Cournoyer, D. Gay, INO (Canada); P. Turbis, Univ. de Montréal (Canada); E. Lorin, Univ. de Montréal (Canada) and Carleton Univ. (Canada); M. Briand, Y. Taillon, INO (Canada)

8967 OP Laser thin film ablation with multiple beams and tailored beam profiles [8967-24]

S. Rung, Univ. of Applied Sciences Aschaffenburg (Germany); C. Bischoff, E. Jäger,

U. Umhofer, TOPAG Lasertechnik GmbH (Germany); R. Hellmann, Univ. of Applied Sciences Aschaffenburg (Germany)

$89670 Q$ High-throughput and high-precision laser micromachining with ps-pulses in synchronized mode with a fast polygon line scanner [8967-25]

B. Jaeggi, B. Neuenschwander, M. Zimmermann, Bern Univ. of Applied Sciences (Switzerland); L. Penning, R. deLoor, Next Scan Technology B.V. (Netherlands);

K. Weingarten, A. Oehler, Time-Bandwidth Products AG (Switzerland) 
8967 OS Precision laser annealing of silicon devices for enhanced electro-optic performance [8967-27]

D. A. Bender, C. T. DeRose, A. Starbuck, J. C. Verley, M. W. Jenkins, Sandia National Labs. (United States)

8967 OT Laser annealing and simulation of amorphous silicon thin films for solar cell applications [8967-28]

I. Theodorakos, Y. S. Raptis, National Technical Univ. of Athens (Greece); V. Vamvakas, HelioSphera SA (Greece); D. Tsoukalas, I. Zergioti, National Technical Univ. of Athens (Greece)

8967 OU Novel industrial laser etching technics for sensors miniaturization applied to biomedical: a comparison of simulation and experimental approach [8967-29]

J. Zelgowski, Icube (France) and IREPA LASER (France) and Lab. Hubert Curien (France); F. Mermet, IREPA LASER (France); F. Antoni, Icube (France); C. Mauclair, Lab. Hubert Curien (France) and GIE Manutech-USD (France); E. Fogarassy, Icube (France); E. Mottay,

Amplitude Systèmes (France)

8967 OV Surface structuring of zirconium-based bulk metallic glasses using ultrashort laser pulses [8967-30]

C. Dold, Inspire AG (Switzerland); M. Kachel, D. Wortmann, RWTH Aachen (Germany); V. Wessels, ETH Zürich (Switzerland); A. Dohrn, Fraunhofer-Institut für Lasertechnik (Germany); A. Bruinink, EMPA (Switzerland); F. Pude, Inspire AG (Switzerland); J. F. Loeffler, ETH Zürich (Switzerland); R. Poprawe, RWTH Aachen (Germany) and Fraunhofer-Institut für Lasertechnik (Germany); K. Wegener, Inspire AG (Switzerland) and ETH Zürich (Switzerland)

\section{APPLICATIONS AND DIAGNOSTICS OF LASER TRANSFER TECHNIQUES: JOINT SESSION WITH CONFERENCES 8967 AND 8970}

8967 0X High-resolution imaging of ejection dynamics in laser-induced forward transfer [8967-32] R. Pohl, C. W. Visser, G. R. B. E. Römer, C. Sun, A. J. Huis in 't Veld, D. Lohse, Univ. Twente (Netherlands)

\section{TIME-RESOLVED DIAGNOSTIC TECHNIQUES}

896710 Synchronized videography of plasma plume expansion during femtosecond laser ablation [8967-36]

S. Paolasini, A. Kietzig, McGill Univ. (Canada)

896711 Ultrafast imaging of free carriers: controlled excitation with chirped ultrafast laser Bessel beams (Best Student Oral Paper Award) [8967-37]

P. K. Velpula, M. K. Bhuyan, C. Mauclair, J. P. Colombier, R. Stoian, Lab. Hubert Curien, CNRS, Univ. de Lyon, Univ. Jean Monnet (France) 
896713 Rapid composition analysis of compound semiconductor thin film solar cell by laser induced breakdown spectroscopy [8967-39]

S. H. Lee, C. K. Kim, J. H. In, S. H. Jeong, Gwangju Institute of Science and Technology (Korea, Republic of)

896714 Modeling of laser patterning of thin-film solar cells [8967-40]

T. Peschel, Fraunhofer-Institut für Angewandte Optik und Feinmechanik (Germany);

G. Matthäus, S. Nolte, Friedrich-Schiller-Univ. Jena (Germany); R. Eberhardt,

A. Tünnermann, Fraunhofer-Institut für Angewandte Optik und Feinmechanik (Germany)

896715 Optimizing process time of laser drilling processes in solar cell manufacturing by coaxial camera control [8967-41]

V. Jetter, Fraunhofer-Institut für Physikalische Messtechnik (Germany); S. Gutscher, Fraunhofer-Institut für Solare Energiesysteme (Germany); A. Blug, Fraunhofer-Institut für Physikalische Messtechnik (Germany); A. Knorz, C. Ahrbeck, J. Nekarda, Fraunhofer-Institut für Solare Energiesysteme (Germany); D. Carl, Fraunhofer-Institut für Physikalische Messtechnik (Germany)

896716 Silver-free solar cell interconnection by laser spot welding of thin aluminum layers: analysis of process limits for ns- and $\mu \mathrm{s}$-lasers [8967-48]

H. Schulte-Huxel, S. Blankemeyer, S. Kajari-Schröder, Institut für Solarenergieforschung Hameln (Germany); R. Brendel, Institut für Solarenergieforschung Hameln (Germany) and Leibniz Univ. of Hanover (Germany)

PHOTOVOLTAICS AND ENERGY DEVICES: JOINT SESSION WITH CONFERENCES 8967 AND 8968

896717 Optimized laser patterning for high performance $\mathrm{Cu}(\mathrm{In}, \mathrm{Ga}) \mathrm{Se}_{2}$ thin-film solar modules [8967-43]

A. Burn, M. Muralt, Bern Univ. of Applied Sciences (Switzerland); R. Witte, Solneva SA

(Switzerland); S. Buecheler, S. Nishiwaki, EMPA (Switzerland); L. Krainer, G. J. Spuehler,

Onefive GmbH (Switzerland); V. Romano, Bern Univ. of Applied Sciences (Switzerland)

\section{POSTER SESSION}

8967 1 A Laser radiation attenuator on the basis of four Dove's prisms [8967-47]

J. Owsik, Military Univ. of Technology (Poland); A. A. Liberman, A. A. Kovalev,

A. S. Mikryukov, S. A. Moskalyuk, M. V. Ulanovsky, All-Russian Research Institute of Optical and Physical Measurements (Russian Federation); J. Noga, Military Univ. of Technology (Poland); A. Rembielińska, LOT Polish Airlines (Poland); J. Walczuk, Agency for Restructuring and Modernisation of Agriculture (Poland)

8967 1B High precision laser forming for microactuation [8967-49]

G. K. G. P. Folkersma, G. R. B. E. Römer, D. M. Brouwer, A. J. Huis in '† Veld, Univ. Twente (Netherlands) 
8967 1C Laser textured substrates for light in-coupling in thin-film solar cells (Best Student Poster Paper Award) [8967-50]

K. Chakanga, O. Siepmann, O. Sergeev, S. Geißendörfer, K. von Maydell, C. Agert, Next Energy, EWE Research Ctr. for Energy Technology (Germany)

8967 1D Smart optical writing head design for laser-based manufacturing [8967-51]

M. J. Amin, N. A. Riza, Univ. College Cork (Ireland)

$8967 \mathrm{lE}$ High quality $\mathrm{ZnO}$ film formation by $\mathrm{CO}_{2}$ laser annealing of buried films in $\mathrm{SiO}_{2}$ matrix [8967-52]

K. Yamasaki, H. Ikenove, T. Shimogaki, Y. Watanabe, D. Nakamura, T. Okada, Kyushu Univ. (Japan)

$89671 \mathrm{~F}$ Selective realignment of the exchange biased magnetization direction in spintronic layer stacks using continuous and pulsed laser radiation [8967-53]

I. Berthold, M. Müller, R. Ebert, J. Schille, U. Löschner, H. Exner, Hochschule Mittweida

(Germany); P. Matthes, M. Albrecht, Technische Univ. Chemnitz (Germany)

8967 IG Shape-controlled ZnO nanocrystals using multi-beam interference irradiation [8967-54]

D. Nakamura, T. Shimogaki, Y. Muraoka, S. Nakao, K. Harada, M. Higashihata, Kyushu Univ. (Japan); Y. Nakata, Osaka Univ. (Japan); T. Okada, Kyushu Univ. (Japan)

$89671 \mathrm{H} \quad$ Performance optimization of electronic circuits laser repair [8967-55]

R. Oron, Orbotech Ltd. (Israel)

$89671 \mathrm{~J} \quad$ Study of fast laser induced cutting of silicon materials [8967-57]

S. Weinhold, A. Gruner, R. Ebert, J. Schille, H. Exner, Hochschule Mittweida (Germany)

Author Index 


\section{Conference Committee}

Symposium Chairs

Bo Gu, Bos Photonics (United States)

Andreas Tünnermann, Fraunhofer-Institut für Angewandte Optik und Feinmechanik (Germany) and Friedrich-Schiller-Universität Jena

(Germany)

Symposium Co-chairs

Guido Hennig, Daetwyler Graphics AG (Switzerland)

Yongfeng Lu, University of Nebraska-Lincoln (United States)

Program Track Chairs

Henry Helvajian, The Aerospace Corporation (United States)

Alberto Piqué, U.S. Naval Research Laboratory (United States)

Conference Chairs

Yoshiki Nakata, Osaka University (Japan)

Xianfan Xu, Purdue University (United States)

Stephan Roth, BLZ Bayerisches Laserzentrum GmbH (Germany)

Beat Neuenschwander, Berner Fachhochschule Technik und

Informatik (Switzerland)

Conference Program Committee

Craig B. Arnold, Princeton University (United States)

J. Thomas Dickinson, Washington State University (United States)

Jan J. Dubowski, Université de Sherbrooke (Canada)

Bo Gu, Bos Photonics (United States)

Guido Hennig, Daetwyler Graphics AG (Switzerland)

Henry Helvajian, The Aerospace Corporation (United States)

Yongfeng Lu, University of Nebraska-Lincoln (United States)

Michel Meunier, Ecole Polytechnique de Montréal (Canada)

Hiroyuki Niino, National Institute of Advanced Industrial Science and Technology (Japan)

Andreas Ostendorf, Ruhr- Universität Bochum (Germany)

Alberto Piqué, U.S. Naval Research Laboratory (United States)

Gediminas Raciukaitis, Center for Physical Sciences and Technology

(Lithuania)

Andrei V. Rode, The Australian National University (Australia)

Pere Serra, Universitat de Barcelona (Spain) 
Klaus Sokolowski-Tinten, Universität Duisburg-Essen (Germany)

Razvan Stoian, Laboratoire Hubert Curien (France)

Koji Sugioka, RIKEN (Japan)

\section{Session Chairs}

1 Laser-induced Modification and Patterning of Surfaces I: Joint Session with Conferences 8967 and 8969

Yoshiki Nakata, Osaka University (Japan)

2 Laser-induced Modification and Patterning of Surfaces II: Joint Session with Conferences 8967 and 8969

Xianfan Xu, Purdue University (United States)

3 Nanomaterial Photonics and Plasmonics I: Joint Session with Conferences 8967 and 8969

Richard F. Haglund Jr., Vanderbilt University (United States)

$4 \quad$ Nanomaterial Photonics and Plasmonics II: Joint Session with Conferences 8967 and 8969

Jan J. Dubowski, Université de Sherbrooke (Canada)

5 Ultrafast Laser-induced Modifications of Transparent Materials: Joint Session with Conferences 8967 and 8972

Stefan Nolte, Friedrich-Schiller-Universität Jena (Germany)

6 Beam Shaping: Joint Session with Conferences 8967 and 8972

Peter R. Herman, University of Toronto (Canada)

7 Adaptive Optics and Beam Shaping: Joint Session with Conferences 8967 and 8972

Stephan Roth, BLZ Bayerisches Laserzentrum GmbH (Germany)

8 Ultrashort Pulse Micromachining: Joint Session with Conferences 8967 and 8972

Andreas Ostendorf, Ruhr-Universität Bochum (Germany)

9 Materials for Energy Conservation

Yongfeng Lu, University of Nebraska-Lincoln (United States)

10 Enhanced Processing by Multi-pulse

Stephan Roth, BLZ Bayerisches Laserzentrum GmbH (Germany)

11 Annealing and Forming of Microstructures

Klaus Sokolowski-Tinten, Universität Duisburg-Essen (Germany) 
12 Applications and Diagnostics of Laser Transfer Techniques: Joint Session with Conferences 8967 and 8970

Masayuki Okoshi, National Defense Academy (Japan)

Daisuke Nakamura, Kyushu University (Japan)

13 Time-resolved Diagnostic Techniques

Masaaki Sakakura, Kyoto University (Japan)

14 Processing and Diagnostics of Photovoltaics

Beat Neuenschwander, Berner Fachhochschule Technik und Informatik (Switzerland)

15 Photovoltaics and Energy Devices: Joint Session with Conferences 8967 and 8968

Yoshiki Nakata, Osaka University (Japan)

Udo Klotzbach, Fraunhofer IWS Dresden (Germany) 
Proc. of SPIE Vol. 8967 896701-12

Downloaded From: https://www.spiedigitallibrary.org/conference-proceedings-of-spie on 25 Apr 2023 Terms of Use: https://www.spiedigitallibrary.org/terms-of-use 